\title{
Correction to: Acute kidney injury with partial Fanconi syndrome in a patient with leptospirosis: a case report
}

\author{
Marc Weiner ${ }^{1 *}\left(0\right.$, Matteo Coen ${ }^{1,3}$, Jacques Serratrice ${ }^{1}$, Thomas A. Mavrakanas ${ }^{2}$ and Antonio Leidi ${ }^{1}$
}

\section{Correction to: J Med Case Reports (2021) 15:358} https://doi.org/10.1186/s13256-021-02978-0

Following publication of the original article [1], the paragraph in the top right part and the paragraph in bottom right part of the page 3 have been interchanged due to a typesetting error.

The original article [1] has been corrected.

\section{Reference}

1. Weiner M, Coen M, Serratrice J, Mavrakanas TA, Leidi A. Acute kidney injury with partial Fanconi syndrome in a patient with leptospirosis: a case report. J Med Case Reports. 2021;15:358.

\section{Publisher's Note}

Springer Nature remains neutral with regard to jurisdictional claims in published maps and institutional affiliations.

\section{Author details}

'Department of General Internal Medicine, Geneva University Hospital, Rue Gabrielle-Perret-Gentil 4, 1205 Geneva, Switzerland. ${ }^{2}$ Division of Nephrology, Department of Medicine, McGill University Health Centre, 1001 Decarie Boulevard, Montreal, OC, Canada. ${ }^{3}$ Unit of Development and Research in Medical Education (UDREM), Faculty of Medicine, University of Geneva, 1211 Geneva, Switzerland.

Published online: 16 August 2021 original author(s) and the source, provide a link to the Creative Commons licence, and indicate if changes were made. The images or other third party material in this article are included in the article's Creative Commons licence, unless indicated otherwise in a credit line to the material. If material is not included in the article's Creative Commons licence and your intended use is not permitted by statutory regulation or exceeds the permitted use, you will need to obtain permission directly from the copyright holder. To view a copy of this licence, visit http://creativecommons.org/licenses/by/4.0/. The Creative Commons Public Domain Dedication waiver (http://creativecommons.org/publicdomain/zero/1.0/) applies to the data made available in this article, unless otherwise stated in a credit line to the data. 